\title{
PENGARUH KINERJA KEUANGAN TERHADAP PERTUMBUHAN EKONOMI DENGAN ALOKASI BELANJA MODAL SEBAGAI VARIABEL INTERVENING
}

\author{
Anisya Ayu L'), Sri Rahayu' ${ }^{2)}$,Junaidi ${ }^{3)}$ \\ ${ }^{1)}$ Alumni Magister Ilmu Akuntansi Pascasarjana Universitas Jambi Tahun 2019 \\ ${ }^{2 \& 3)}$ Dosen Pembimbing
}

\begin{abstract}
This study aimed to examine the effect of financial performance on economic growth with the allocation of capital expenditure as an intervening variable in District/City Governments in Jambi Province. The financial performance variables measured were the degree of fiscal decentralization, growth of PAD, effectiveness of PAD, financial efficiency and BUMD's contribution. Data analyzed using path analysis with AMOS program were based on secondary data in the form of panel data sourced from district/city APBD datas in Jambi Province. The results showed that only the degree of fiscal decentralization, the effectiveness of PAD and financial efficiency had direct effect on the allocation of capital expenditure. In addition, only growth of PAD, effectiveness of PAD, financial efficiency and allocation of capital expenditures had direct effect on economic growth. The capital expenditure allocation variable only partially mediated the effect of the fiscal decentralization, PAD effectiveness and financial efficiency on economic growth.
\end{abstract}

Keywords: Financial Performance, Capital Expenditure, Economic Growth.

\begin{abstract}
ABSTRAK
Penelitian ini bertujuan untuk menguji pengaruh kinerja keuangan terhadap pertumbuhan ekonomi dengan alokasi belanja modal sebagai variabel intervening pada Pemerintah Kabupaten/Kota di Provinsi Jambi. Variabel kinerja keuangan yang diukur adalah derajat desentralisasi fiskal, pertumbuhan PAD, efektivitas PAD, Efisiensi Keuangan dan Kontribusi BUMD. Data dianalisis dengan analisis jalur menggunakaan program AMOS berdasarkan data sekunder berbentuk data panel yang bersumber dari data APBD Kabupaten/Kota di Provinsi Jambi. Hasil penelitian menunjukkan bahwa hanya derajat desentralisasi fiskal, efektivitas PAD dan efisiensi keuangan yang berpengaruh langsung terhadap alokasi belanja modal. Selain itu, hanya variabel pertumbuhan PAD, efektivitas PAD, efisiensi keuangan dan alokasi belanja modal yang berpengaruh langsung terhadap pertumbuhan ekonomi. Variabel alokasi belanja modal hanya memediasi secara parsial pengaruh variabel derajat desentralisasi fiskal, efektivitas PAD dan efisiensi keuangan terhadap pertumbuhan ekonomi.
\end{abstract}

Kata Kunci: Kinerja Keuangan, Belanja Modal, Pertumbuhan Ekonomi. 


\section{PENDAhuluan}

\subsection{LatarBelakang}

Pelaksanaan desentralisasi fiskal di Indonesia mengacu pada Undang-Undang Nomor 22 Tahun 1999 tentang Pemerintahan Daerah yang telah direvisi menjadi Undang-Undang Nomor 23 Tahun 2014 dan Undang-Undang Nomor 25 Tahun 1999 tentang Perimbangan Keuangan antara Pusat dan Daerah yang direvisi menjadi Undang-Undang Nomor 33 Tahun 2004. Kedua undang-undang di bidang otonomi daerah tersebut telah menetapkan pemberian kewenangan otonomi dalam wujud otonomi yang luas, nyata, dan bertanggung jawab kepada daerah, pemerintah daerah diberi wewenang untuk menggali potensi daerahnya dan menetapkan prioritas pembangunan.

Provinsi Jambi merasakan dampak dari diberlakukannya kebijakan otonomi daerah khususnya dalam menyusun Anggaran Pendapatan dan Belanja Daerah yang berlandaskan UndangUndang Nomor 23 Tahun 2014 tentang Pemerintah Daerah. Pada Undang-Undang No. 23 Tahun 2014 tentang Pemerintah Daerah, pemerintah pusat memberikan kewenangan penuh bagi tiap-tiap daerah baik provinsi, kabupaten/ kota untuk mengatur dan mengurus rumah tangga daerahnya dengan sedikit mungkin campur tangan pemerintah pusat.

Pengelolaan keuangan daerah yang baik tidak hanya membutuhkan sumber daya manusia yang handal tetapi juga harus didukung oleh kemampuan keuangan daerah yang memadai.Upaya pemerintah daerah dalam menggali kemampuan daerah dapat diukur menggunakan analisis rasio keuangan pemerintah daerah.Pengukuran kinerja pemerintah daerah dapat dijadikan sebagai penilaian akuntabilitas dan kemampuan suatu daerah penyelenggara otonomi daerah.Dengan demikian, suatu daerah yang kinerja keuangannya dinyatakan baik berarti daerah tersebut memiliki kemampuan keuangan untuk membiayai pelaksanaan otonomi daerah (Sularso dan Restianto, 2011).

Pemberian otonomi daerah memang berpengaruh terhadap pertumbuhan ekonomi suatu daerah karena memberikan kebebasan kepada pemerintah daerah untuk membuat rencana keuangannya sendiri dan membuat kebijakankebijakan yang dapat berpengaruh pada kemajuan daerahnya. Pertumbuhan ekonomi mendorong pemerintah daerah untuk melakukan pembangunan ekonomi dengan mengelola sumber daya yang ada dan membentuk lapangan kerja baru yang akan mempengaruhi perkembangan kegiatan ekonomi daerah tersebut.

Kenyataan yang terjadi dalam pemerintahan saat ini adalah adanya peningkatan pertumbuhan ekonomi ternyata tidak selalu diikuti dengan peningkatan alokasi belanja modal yang dianggarkan lebih kecil dari belanja pegawai dari total anggaran belanja tiap tahunnya (Utomo, 2012). Padahal, belanja modal merupakan stimulus bagi pertumbuhan ekonomi daerah.Pemerintah memang perlu untuk meningkatkan investasi modal guna meningkatkan pertumbuhan ekonomi daerah (Lin dan Liu, 2000 dalam Kawa, 2011).

\subsection{RumusanMasalah}

Berdasarkan latar belakang di atas, maka rumusan masalah dalam penelitian ini adalah sebagai berikut.

1. Bagaimanakah pengaruh langsung Kinerja Keuangan terhadap Pertumbuhan Ekonomi Daerah dengan Alokasi Belanja Modal sebagai Variabel Intervening?

2. Bagaimanakah pengaruh tidak langsung Kinerja Keuangan terhadap Pertumbuha Ekonomi Daerah dengan Alokasi Belanja Modal sebagai Variabel Intervening?

\section{TINJAUAN PUSTAKA, KERANGKA PEMIKIRAN DAN HIPOTESIS}

\subsection{Tinjauan Pustaka}

\subsubsection{Rasio Derajat Desentralisasi Fiskal}

Derajat Desentralisasi Fiskal atau disebut dengan Derajat Otonomi Fiskal (DOF) daerah merupakan aspek sangat penting dalam pelaksanaan otonomi daerah secara keseluruhan.Hal ini disebabkan derajat otonomi fiskal merupakan gambaran kemampuan daerah dalam meningkatkan pendaptan asli daerah seperti pajak daerah, retribusi daerah, dan sumber-sumber lainnya.

Dalam hal ini, derajat desentralisasi menunjukan derajat kontribusi PAD terhadap total pendaptan daerah. Semakin tinggi kontribusi PAD, maka semakin tinggi kemampuan daerah dalam penyelenggaraan desentralisasi. Derajat desentralisasi dihitung dengan formula sebagai berikut (BPKP, 2012):

$$
\begin{aligned}
& \text { Rasio Derajat Desentralisasi } \\
& =\frac{\text { PAD }}{\text { TotalPendapatan }} \times 100 \%
\end{aligned}
$$

\subsubsection{Rasio Pertumbuhan PAD}

Rasio pertumbuhan mengukur seberapa besar kemampuan pemerintah daerah dalam mempertahankan dan meningkatkan keberhasilannya yang telah dicapai dari periode ke periode berikutnya. Dengan diketahuinya pertumbuhan untuk masingmasing komponen sumber pendapatan dan pengeluaran, dapat digunakan untuk mengevaluasi potensi-potensi mana yang perlu mendapat perhatian.

$$
\text { Rasio Pertumbuhan PAD }=\frac{\text { PADt }- \text { PADt }-1}{\text { PADt }-1} \times 100 \%
$$

\subsubsection{Rasio Efektivitas PAD}

Rasio efektivitas mengambarkan kemampuan pemerintah dalam merelaisasikan Pendaptan Asli 
Daerah yang direncanakan dibandingkan dengan target yang ditetapkan berdasarkan potensi riil. Semakin tinggi rasio efektivitas keuangan daerah maka daerah telah menggunakan APBD secara efektif dalam membiayai kegiatan atau program kerja dalam rangka melaksanakan pembangunan dan mensejahterakan masyarakatnya atau sebaliknya. Rasio efektivitas PAD dapat dihitung dengan rumus sebagai berikut (Halim, 2013) :

\section{Rasio Efektivitas =

$\frac{\text { RealisasiPendapatan }}{\text { targetpenerimaanPADyangditetapkan }} \times 100 \%$

\subsubsection{Rasio Efisiensi keuangan}

Efisien keuangan daerah diukur dengan membandingkan total pengeluaran daerah dengan total pendaptan daerah. Semakin kecil nilai efisiensi maka akan semakin efisiensi suatu daerah. Hal ini menyiratkan pengeluaran yang dibelanjakan sesuai dengan yang telah direncanakan.

\section{Rasio Efisiensi $=\frac{\text { RealisasiPengeluaran }}{\text { RealisasiPenrimaan }} \times 100 \%$}

Dengan mengetahui hasil perbandingan antara realisasi pengeluaran dan realisasi penerimaan dengan menggunakan ukuran efisiensi tersebut maka penilaian kinerja keuangan dapat ditentukan (Medi, 1966 dalam Budiarto, 2007). Apabila kinerja keuangan diatas $100 \%$ ke atas dapat dikatakan tidak efisien 90\%-100\% adalah kurang efisien, 80\%-90\% adalah cukup efisien, $60 \%-80 \%$ adalah efisien dan dibawah dari $60 \%$ adalah sangat efisien.

\subsubsection{Rasio Kontribusi BUMD}

Rasio Kontribusi BUMD digunakan untuk mengetahui tingkat kontribusi perusahaan daerah/BUMD dalam mendukung pendapatan daerah.Semakin tinggi rasio ini berdampak pada naiknya pendapatan daerah (BPKP, 2012).

\section{RasioKontribusiBUMD $=\frac{\text { PenerimaanBUMD }}{\text { TotalPAD }} \times 100 \%$}

\subsubsection{Belanja Modal}

Belanja modal sangat erat kaitannya dengan investasi yang dilakukan oleh pemerintah daerah. Dalam PP No.58 tahun 2005 disebutkan bahwa belanja modal adalah pengeluaran yang dilakukan dalam rangka pembelian/pengadaan aset tetap dan aset lainnya yang mempunyai masa manfaat lebih dari 12 (dua belas) bulan untuk digunakan dalam kegiatan pemerintahan, seperti dalam bentuk tanah, peralatan, dan mesin, gedung, dan bangunan, jaringan, buku perpustakaan dan hewan.

$$
\text { RasioBelanjaModal }=\frac{\text { BelanjaModal }}{\text { TotalBelanja }} \times 100
$$

\subsubsection{Pertumbuhan Ekonomi}

Pertumbuhan ekonomi adalah angka yang ditunjukkan oleh besarnya tingkat pertumbuhan produk domestik regional bruto suatu daerah yang diukur atas dasar harga konstan. Bagi suatu daerah provinsi, kabupaten/kota gambaran PDRB yang mencerminkan adanya laju pertumbuhan ekonomi dapat dilihat dalam data sektor-sektor ekonomi yang meliputi pertanian, pertambangan dan penggalian, industri pengolahan, listrik gas dan air bersih, bangunan, perdagangan hotel dan restoran, pengangkutan dan komunikasi, keuangan persewaan dan jasa perusahaan dan jasa-jasa lainnya. Pertumbuhan ekonomi daerahdirumuskan sebagai berikut:

$$
\mathrm{PED}=\frac{P D R B(t)-P D R B(t-1)}{P D R B(t-1)} x 100 \%
$$

Dimana:

PED = PertumbuhanEkonomi Daerah

$\operatorname{PDRB}_{(\mathrm{t})} \quad=$ Produk Domestik Regional BrutoPeriode Tertentu

$\operatorname{PDRB}_{(\mathrm{t}-1)}=$ Produk Domestik Regional Bruto Periode Sebelumnya

\subsection{Kerangka Pemikiran}

Otonomi daerah menurut Undang-Undang adalah hak, wewenang dan kewajiban daerah otonom untuk mengatur dan mengurus sendiri urusan pemerintahan dan kepentingan masyarakat setempat sesuai dengan peraturan perundang-undangan. Kewenangan pemerintah daerah berkaitan dengan pengelolaan sumber daya yang dimiliki sesuai dengan kepentingan, prioritas, dan potensi daerah tersebut. Oleh karena itu, pemerintah daerah diharuskan untuk mengelola keuangannya sendiri.

Undang-Undang No. 23 Tahun 2014 menyebutkan bahwa untuk pelaksanaan kewenangan Pemerintah Daerah, Pemerintah Pusat akan mentransfer Dana Perimbangan yang terdiri dari Dana Alokasi Umum (DAU), Dana Alokasi Khusus (DAK) dan Dana Bagi Hasil (DBH) yang bersumber dari pajak dan sumber daya alam. Di samping dana perimbangan tersebut, Pemda mempunyai sumber pendanaan sendiri berupa Pendapatan Asli Daerah (PAD), Pembiayaan dan lain-lain. Oleh karena itu, pemerintah kabupaten/ kota diharapkan dapat menggunakan dana ini dengan efektif dan efisien disertai pertanggung jawaban atas penggunaan dana tersebut untuk peningkatan pelayanan pada masyarakat sehingga tercipta kesejahteraan masyarakat.

\subsection{Hipotesis}

Berdasarkan model penelitian diatas dan hasil penelitian sebelumnya, maka penulis merumuskan hipotesis sebagai berikut: 
$\mathrm{H}_{1}$ : Desentralisasi Fiskal berpengaruh terhadap alokasi belanja modal.

$\mathrm{H}_{2}$ : Pertumbuhan PAD berpengaruh terhadap alokasi belanja modal.

$\mathrm{H}_{3}$ : Efektivitas PAD berpengaruh terhadap alokasi belanja modal.

$\mathrm{H}_{4}$ : Efisiensi Keuangan berpengaruh terhadap alokasi belanja modal.

$\mathrm{H}_{5}$ : Kontribusi BUMD berpengaruh terhadap alokasi belanja modal.

$\mathrm{H}_{6}$ : Derajat Desentralisasi Fiskal berpengaruh terhadap Pertumbuhan Ekonomi Daerah.

$\mathrm{H}_{7}$ : Pertumbuhan PAD berpengaruh terhadap Pertumbuhan Ekonomi Daerah.

$\mathrm{H}_{8}$ : Efektivitas PAD berpengaruh terhadap Pertumbuhan Ekonomi Daerah.

$\mathrm{H}_{9}$ : Efisiensi Keuangan berpengaruh terhadap Pertumbuhan Ekonomi Daerah.

$\mathrm{H}_{10}$ : Kontribusi BUMD berpengaruh terhadap Pertumbuhan Ekonomi Daerah.

$\mathrm{H}_{11}$ : Alokasi Belanja Modal berpengaruh terhadap Pertumbuhan Ekonomi Daerah.

$\mathrm{H}_{12}$ : Alokasi Belanja Modal memediasi Pengaruh Rasio Desentralisasi Fiskal terhadap Pertumbuhan Ekonomi.

$\mathrm{H}_{13}$ : Alokasi Belanja Modal memediasi Pengaruh Pertumbuhan PAD terhadap Pertumbuhan Ekonomi Daerah.

$\mathrm{H}_{14}$ : Alokasi Belanja Modal memediasi Pengaruh Efektivitas PAD Daerah terhadap Pertumbuhan Ekonomi Daerah.

$\mathrm{H}_{15}$ : Alokasi Belanja Modal memediasi Pengaruh Efiseiensi Keuangan Daerah terhadap Pertumbuhan Ekonomi Daerah.

$\mathrm{H}_{16}$ : Alokasi Belanja Modal memediasi Pengaruh Derajat Kontribusi BUMD terhadap Pertumbuhan Ekonomi Daerah.

\section{METODOLOGI PENELITIAN}

\subsection{Jenis dan Sumber Data}

Data yang digunakan dalam penelitian ini berdasarkan pengelompokkan sumbernya adalah data sekunder.Data sekunder adalah data data yang sudah tersedia dan dikumpulkan oleh pihak lain (Sanusi, 2011).Penelitian ini menggunakan data sekunder yang bersumber dari Badan Pusat Statistik yang di akses melalui website BPS masing-masing kabupaten kota berupa data PDRB, dan data APBD kabupaten/kota provinsi Jambi diambil dari BPS Provinsi Jambi.
Adapun kriteria yang digunakan dalam penelitian ini yaitu :

1. Kabupaten/Kota yang melaporkan APBD pada kementerian keuangan dan dipublikasikan pada situs Dirjen Perimbangan Keuangan Daerah selama periode 2013-2017.

2. Kabupaten/Kota dengan data realisasi APBD dimana terdapat Pendapatan Asli Daerah (PAD), Dana Perimbangan, PDRB, dan Belanja modal.

\subsection{Metode Analisis Data}

Metode analisis yang dipilih dalam penelitian ini untuk menganalisis data adalah menggunakan analisa jalur (path analysis) dengan Program AMOS berdasarkan data sekunder berupa data panel. Data tersebut merupakan gabungan antara data silang (cross section) dengan data runtut waktu (time series).

\subsection{Uji Regresi}

Metode analisis data dalam penelitian ini menggunakan analisis jalur (path analysis) dengan program AMOS. Analisis jalur merupakan perluasan dari analisis regresi linier berganda, atau analisis jalur adalah penggunaan analisis regresi untuk menaksir hubungan kausalitas antar variabel yang telah ditetapkan sebelumnya berdasarkan teori (Ghozali, 2011). Secara matematika, analisis jalur mengikuti pola model struktural sebagai berikut:

1. Sub Struktur I Y $=\mathrm{P} \mathrm{YX}_{1}+\mathrm{P} \mathrm{YX}_{2}+\mathrm{P} \mathrm{YX}_{3}+\mathrm{P}$ $\mathrm{YX}_{4}+\mathrm{P} \mathrm{YX}_{5}+\rho \mathrm{Y} \varepsilon_{1}$

2. Sub Struktur II $Z=P Z X_{1}+P X_{2}+P Z X_{3}+P$ $Z_{4}+P Z X_{5}+P Z Y+\rho Z \varepsilon_{2}$

Dimana:

$\mathrm{Z}=$ Belanja Modal

$\mathrm{Y}=$ Pertumbuhan Ekonomi

$\mathrm{X}_{1}=$ Desentralisasi Fiskal

$\mathrm{X}_{2}=$ Rasio Pertumbuhan PAD

$\mathrm{X}_{3}=$ Rasio Efektivitas

$\mathrm{X}_{4}=$ Rasio Efisiensi

$\mathrm{X}_{5}=$ Rasio Kontribusi BUMD

$\mathrm{P}=$ Koefesien regresi

$\mathrm{Y} \varepsilon_{1}=$ Variabel lainnya yang mempengaruhi

$\mathrm{Y} \varepsilon_{2}=$ Variabel lainnya yang mempengaruhi $\mathrm{Z}$

Uji hipotesis yang dilakukan adalah Uji t (uji parsial) dan uji koefisien determinasi.

\section{HASIL DAN PEMBAHASAN}

\subsection{Hasil Penelitian}

\subsubsection{Analisis Data}

Analisis data dalam penelitian ini dilakukan menggunakan analisis jalur dengan alat bantu 
softawre AMOS 24.00. Spesifikasi model yang dihasilkan dapat dilihat pada gambar berikut.

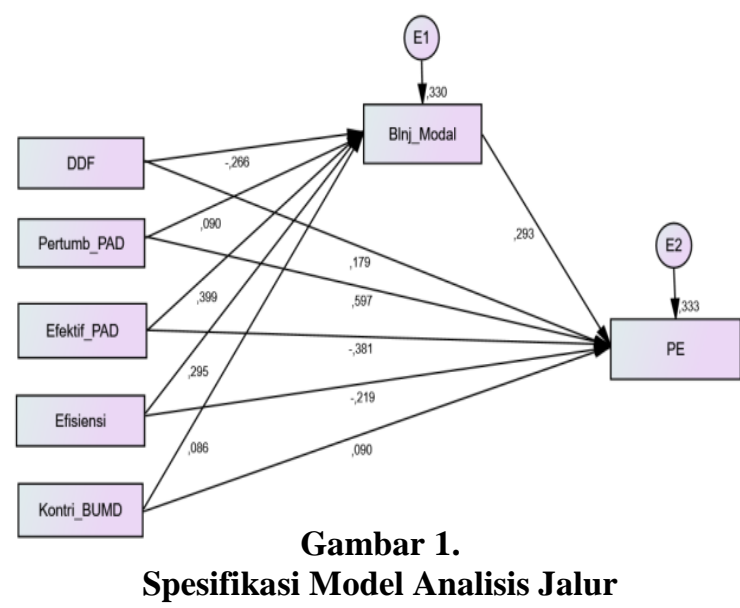

Gambar 1. menunjukkan nilai koefisien terstandar pada masing-masing pengaruh variabel eksogen terhadap variabel endogennya. Koefisien terstandar ini nilainya sudah standar dari 0-1, dimana semakin mendekati satu maka efek variabel eksogen terhadap variabel endogennya semakin besar. Persamaan analisis jalurnya adalah sebagai berikut:

$$
\begin{array}{r}
\text { Blnj_Modal }=-0,266 \text { DDF }+ \text { 0,090 Pertumb_PAD + } \\
\text { 0,399 Efektif_PAD }+0,295 \\
\text { Efisiensi }+ \text { 0,086 Kontri_BUMD }
\end{array}
$$

$$
\begin{aligned}
\mathrm{PE}= & 0,179 \mathrm{DDF}+0,597 \text { Pertumb_PAD }-0,381 \\
& \text { Efektif_PAD - 0,219 Efisiensi }+0,090 \\
& \text { Kontri_BUMD }
\end{aligned}
$$

\subsubsection{Uji Hipotesis}

Pengujian hipotesis dilakukan dengan menggunakan uji t pada taraf signifikansi $\alpha=0,1$. Kriteria keputusan dilihat nilai probabilitas dari setiap koefisien masing-masing variabel independen dibandingkan dengan taraf signifikansi $\alpha=0,1$. Hasil pengujian hipotesis yaitu sebagai berikut:

Tabel 1.

Hasil Analisis Regresi

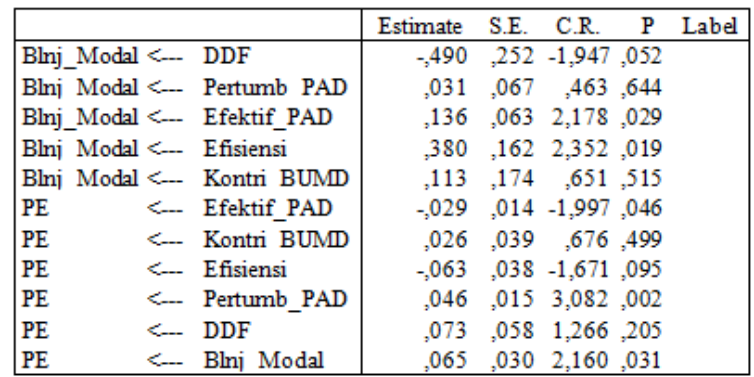

Berdasarkan tabel di atas dapat dikemukakan hasil pengujian hipotesis sebagai berikut:

1. Nilai probability (p) sebesar 0,052 lebih kecil dari taraf signifikansi 0,1 . Hal ini berarti bahwa
$\mathrm{H}_{0}$ ditolakdan $\mathrm{H}_{\mathrm{a}}$ diterima, dengan demikian derajat desentralisasi fiskal berpengaruh langsung terhadap alokasi belanja modal.

2. Nilai probability (p) sebesar 0,644 lebih besar dari taraf signifikansi 0,1 . Hal ini berarti bahwa $\mathrm{H}_{0}$ diterima dan $\mathrm{H}_{\mathrm{a}}$ ditolak, dengan demikian pertumbuhan PAD tidak berpengaruh langsung terhadap alokasi belanja modal.

3. Nilai probability (p) sebesar 0,029 lebih kecil dari taraf signifikansi 0,1 . Hal ini berarti bahwa $\mathrm{H}_{0}$ ditolak dan $\mathrm{H}_{\mathrm{a}}$ diterima, dengan demikian efektivitas PAD berpengaruh langsung yang signifikan terhadap alokasi belanja modal.

4. Nilai probability (p) sebesar 0,019 lebih kecil dari taraf signifikansi 0,1 . Hal ini berarti bahwa $\mathrm{H}_{0}$ ditolakdan $\mathrm{H}_{\mathrm{a}}$ diterima,dengan demikian efisiensi berpengaruh langsung yang signifikan terhadap alokasi belanja modal.

5. Nilai probability (p) sebesar 0,515 lebih besar dari taraf signifikansi 0,1 . Hal ini berarti bahwa $\mathrm{H}_{0}$ diterima dan $\mathrm{H}_{\mathrm{a}}$ ditolak, dengan demikian pertumbuhan PAD tidak berpengaruh langsung terhadap alokasi belanja modal.

6. Nilai probability (p) sebesar 0,205 lebih besar dari taraf signifikansi 0,1 . Hal ini berarti bahwa $\mathrm{H}_{0}$ diterima dan $\mathrm{H}_{\mathrm{a}}$ ditolak, dengan demikian derajat desentralisasi fiskal tidak berpengaruh langsung terhadap pertumbuhan ekonomi.

7. Nilai probability (p) sebesar 0,002 lebih kecil dari taraf signifikansi 0,1 . Hal ini berarti bahwa $\mathrm{H}_{0}$ ditolak dan $\mathrm{H}_{\mathrm{a}}$ diterima, dengan demikian pertumbuhan PAD berpengaruh langsung yang signifikan terhadap pertumbuhan ekonomi.

8. Nilai probability (p) sebesar 0,046 lebih kecil dari taraf signifikansi 0,1 . Hal ini berarti bahwa $\mathrm{H}_{0}$ ditolak dan $\mathrm{H}_{\mathrm{a}}$ diterima, dengan demikianefektivitas PAD berpengaruh langsung yang signifikan terhadap pertumbuhan ekonomi.

9. Nilai probability (p) sebesar 0,095 lebih kecildari taraf signifikansi 0,1 . Hal ini berarti bahwa $\mathrm{H}_{0}$ ditolak dan $\mathrm{H}_{\mathrm{a}}$ diterima, dengan demikian efisiensi berpengaruh langsung terhadap pertumbuhan ekonomi.

10. Nilai probability (p) sebesar 0,499 lebih besar dari taraf signifikansi 0,1 . Hal ini berarti bahwa $\mathrm{H}_{0}$ diterima dan $\mathrm{H}_{\mathrm{a}}$ ditolak, dengan demikian rasio pertumbuhan PAD tidak berpengaruh langsung terhadap pertumbuhan ekonomi.

11. Nilai probability (p) sebesar 0,031 lebih kecil dari taraf signifikansi 0,1 . Hal ini berarti bahwa $\mathrm{H}_{0}$ ditolak dan $\mathrm{H}_{\mathrm{a}}$ diterima, dengan demikian belanja modal berpengaruh langsung yang signifikan terhadap pertumbuhan ekonomi.

12. Nilai probability (p) pengaruh derajat desentralisasi fiskal terhadap belanja modal sebesar 0,052 lebih kecil dari taraf signifikansi 0,1 , sedangkan nilai probability (p) pengaruh belanja modal terhadap pertumbuhan ekonomi sebesar 0,031 lebih kecil dari taraf signifikansi 0,1. Ini berarti $\mathrm{H}_{0}$ ditolak dan $\mathrm{H}_{\mathrm{a}}$ diterima, 
dengan demikian belanja modal memediasi pengaruh derajat desentralisasi fiskal terhadap pertumbuhan ekonomi.

13. Nilai probability (p) pertumbuhan PAD berpengaruh terhadap belanja modal sebesar 0,644 lebih besar dari taraf signifikansi 0,1 , sedangkan nilai probability (p) belanja modal berpengaruh terhadap pertumbuhan ekonomi sebesar 0,031 lebih kecil dari taraf signifikansi 0,1. Ini berarti $\mathrm{H}_{0}$ diterima dan $\mathrm{H}_{\mathrm{a}}$ ditolak, dengan demikian belanja modal tidak memediasi pengaruh pertumbuhan PAD terhadap pertumbuhan ekonomi.

14. Nilai probability (p) efektivitas PAD berpengaruh terhadap belanja modal sebesar 0,029 lebih kecil dari taraf signifikansi 0,1 , sedangkan nilai probability ( $p$ ) belanja modal berpengaruh terhadap pertumbuhan ekonomi sebesar 0,031 lebih kecil dari taraf signifikansi 0,1. Ini berarti $\mathrm{H}_{0}$ ditolak dan $\mathrm{H}_{\mathrm{a}}$ diterima, dengan demikian belanja modal memediasi pengaruh efektivitas PAD terhadap pertumbuhan ekonomi.

15. Nilai probability (p) efisiensi PAD berpengaruh terhadap belanja modal sebesar 0,019 lebih kecil dari taraf signifikansi 0,1 , sedangkan nilai probability (p) belanja modal berpengaruh terhadap pertumbuhan ekonomi sebesar 0,031 lebih kecil dari taraf signifikansi 0,1. Ini berarti $\mathrm{H}_{0}$ ditolak dan $\mathrm{H}_{\mathrm{a}}$ diterima, dengan demikian belanja modal memediasi pengaruh efisiensi terhadap pertumbuhan ekonomi.

16. Nilai probability (p) kontribusi BUMD berpengaruh terhadap belanja modal sebesar 0,515 lebih besar dari taraf signifikansi 0,1 , sedangkan nilai probability (p) belanja modal berpengaruh terhadap pertumbuhan ekonomi sebesar 0,031 lebih kecil dari taraf signifikansi 0,1. Ini berarti $\mathrm{H}_{0}$ diterima dan $\mathrm{H}_{\mathrm{a}}$ ditolak, dengan demikian belanja modal tidak memediasi pengaruh kontribusi BUMD terhadap pertumbuhan ekonomi.

\subsection{Pembahasan}

\subsubsection{Pengaruh Desentralisasi Fiskal terhadap Alokasi Belanja Modal}

Hasil penelitian menunjukkan bahwa derajat desentralisasi fiskal berpengaruh signifikan terhadap alokasi belanja modal. Dengan demikian, perkembangan derajat desentralisasi fiskal Kabupaten/Kota di Provinsi Jambi mempengaruhi kebijakan pemerintah daerah dalam mengalokasikan belanja modalnya. Namun hasil penelitian ini menunjukkan adanya pengaruh desentralisasi fiskal terhadap alokasi belanja modal dengan arah yang negatif. Hal ini berarti bahwa semakin tinggi derajat desentralisasi fiskal, maka alokasi belanja modal daerah justru semakin rendah.
Proporsi PAD dalam total pendapatan daerah yang merupakan indikator yang menunjukkan bagaimana derajat desentralisasi fiskal pada wilayah Kabupaten/Kota di Provinsi Jambi masih relatif rendah. Rata-rata derajat desentralisasi fiskal Kabupaten/Kota di Provinsi Jambi dalam periode penelitian tahun 2013 -2017 hanya sebesar 7,39\%. Hal ini berarti bahwa besarnya PAD dalam total penerimaan daerah di Kabupaten/Kota Jambi berada pada nilai di bawah 10\%. Dengan demikian, penerimaan PAD tidak akan mampu mempengaruhi kebijakan alokasi belanja daerah, sehingga daerah lebih tergantung kepada arahan kebijakan pemerintah pusat dalam mengalokasikan belanja daerah termasuk alokasi belanja modal.

Kecenderungan daerah dengan proporsi PAD lebih rendah dalam total penerimaan daerah mengalokasikan belanja modal lebih besar dibandingkan dengan daerah dengan proporsi PAD yang lebih besar dalam total penerimaan daerahnya. Hal ini dikarenakan adanya kebijakan pemerintah terutama yang dipengaruhi oleh arahan dari pemerintah pusat untuk memberikan alokasi belanja modal lebih besar pada daerah-daerah yang justru PAD-nya masih relatif kecil. Adanya arah kebijakan pada daerah dengan PAD yang masih relatif kecil untuk mengalokasikan belanja modal yang justru lebih besar dimaksudkan supaya daerah dimaksud menjadi lebih berkembang sehingga mampu mendukung pertumbuhan ekonomi dan kesejahteraan masyarakat.

Hasil penelitian ini sejalan dengan penelitian dari Arsa dan Setiawian (2015), Praza (2016) dan Huda (2015) yang menemukan bahwa derajat desentralisasi berpengaruh positif signifikan terhadap alokasi belanja modal. Tetapi tidak sejalan dengan penelitian Suwandi dan Tahar (2015) menemukan pengaruh negatif signifikan derajat desentralisasi fiscal pada alokasi belanja modal. Rasio desentralisasi fiskal ditemukan tidak berpengaruh pada alokasi belanja modal oleh Badaruddin (2011), Sularso dan Restianto (2011) dan Tamawiwy dkk (2016).

\subsubsection{Pengaruh Pertumbuhan PAD terhadap Alokasi Belanja Modal}

Hasil penelitian menunjukkan bahwa pertumbuhan PAD tidak berpengaruh signifikan terhadap alokasi belanja modal. Hal ini berarti bahwa adanya pertumbuhan PAD tahun berjalan dibandingkan dengan PAD tahun sebelumnya tidak mampu meningkatkan alokasi belanja modal. Kemampuan daerah untuk meningkatan sumber penerimaan PAD yang diukur dengan pertumbuhan PAD ternyata belum secara signifikan mempengaruhi alokasi belanja modal daerah.

Besarnya PAD dalam proporsi pendapatan daerah pada Kabupaten/Kota di Provinsi Jambi masih tergolong kecil dengan rata-rata sebesar 7,39\%. Rendahnya proporsi PAD dalam total pendapatan 
daerah menunjukkan bahwa sumber penerimaan daerah masih sangat bergantung pada alokasi pendapatan daerah yang berasal dari pemerintah pusat. Adanya ketergantungan daerah terhadap alokasi penerimaan yang bersumber dari pemerintah pusat membuat pemerintah daerah tidak mampu meningkatkan alokasi belanja modal. Untuk meningkatkan anggaran Belanja Modal maka pemerintah daerah harus mampu meningkatkan Total Pendapatan Daerah di antaranya melalui peningkatan PAD. Oleh karena itu, apabila PAD rendah maka Total Pendapatan Daerah juga rendah sehingga kemampuan pemerintah kabupaten/kota dalam meningkatkan anggaran Belanja Langsung yang didalamnya terdapat Belanja Modal juga rendah. Karena masih rendahnya proporsi PAD dalam total penerimaan daerah membuat perkembangan penerimaan PAD yang diukur menggunakan pertumbuhan PAD tidak berpengaruh signifikan terhadap alokasi belanja modal.

Hasil penelitian ini tidak sejalan dengan Darwanto dan Yustikasari (2007), Tuasikal (2008), Kussnandar dan Doddik (2012) yang menemukan Pertumbuhan PAD berpengaruh positif signifikan terhadap alokasi belanja modal. Tetapi penelitian ini sejalan dengan penelitian Yovita (2011) yang mengatakan pertumbuhan PAD tidak berpengaruh terhadap alokasi belanja modal.

\subsubsection{Pengaruh Efektivitas PAD terhadap Alokasi Belanja Modal}

Hasil penelitian menunjukkan bahwa efektivitas PAD berpengaruh signifikan terhadap alokasi belanja modal. Hal ini berarti bahwa kemampuan pemerintah memaksimalkan kinerjanya dalam mencapai target pendapatan yang berasal dari PAD secara signifikan berimbas terhadap peningkatan alokasi belanja modal. Semakin efektif kinerja pemerintah daerah dalam mencapai target penerimaan PAD, maka alokasi pendanaan belanja daerah juga semakin meningkat. Dengan adanya peningkatan penerimaan PAD karena kemampuan daerah mencapai target penerimaan yang ditetapkan membuat pemerintah daerah lebih leluasa dalam mengalokasikan belanja daerah terutama alokasi belanja daerah yang berhubungan secara langsung dengan peningkatan pelayanan publik seperti alokasi belanja modal.

Hasil penelitian ini sejalan dengan penelitian dari Hidayat (2013), Suwandi dan Tahar (2015), Arsa dan Setiawina (2015) dan Jatitmas (2015) yang menemumkan efektivitas berpengaruh positif signifikan pada alokasi belanja modal. Tetapi penelitian ini tidak sejalan dengan Praza (2016) yang menemukan bahwa efektivitas PAD tidak berpengaruh terhadap alokasi belanja modal.

\subsubsection{Pengaruh Efisiensi Keuangan terhadap Alokasi Belanja Modal}

Hasil penelitian menunjukkan bahwa variabel efisiensi keuangan secara signifikan berpengaruh terhadap alokasi belanja modal. Hal ini berarti bahwa semakin efisien kinerja pemerintah dalam mengelola keuangan daerah membuat pengalokasian belanja modal dalam alokasi belanja daerah juga mengalami peningkatan.

Rasio efisiensi menunjukkan perbandingan antara pengeluaran pemerintah daerah terhadap total pendapatan daerah. Rasio ini menunjukkan kinerja pemerintah dalam mengelola keuangan daerah sehingga pengeluaran pemerintah lebih kecil dari total pendapatan daerah. Semakin kecil alokasi belanja dibandingkan dengan total pendapatan daerah menunjukkan bahwa pengelolaan keuangan daerah cenderung lebih efisien. Jika pendapatan daerah melebih nilai alokasi belanja berarti bahwa daerah memiliki sumber dana yang jauh lebih besar dari jumlah pengeluaran yang dialokasikan. Dengan demikian, apabila nilai pendapatan daerah lebih tinggi dari alokasi belanja menunjukkan adanya surplus pendapatan sedangkan semua alokasi belanja yang dianggarkan mampu terealisasi dengan baik.

Efisiensi keuangan daerah menjadi tolok ukur kinerja keuangan daerah yang menunjukkan bagaimana daerah mampu mengelola keuangannya dengan baik. Kinerja keuangan daerah yang efisien berarti daerah mampu melaksanakan kebijakan pembangunan pada tahun berjalan dengan memaksimalkan pendapatan yang diterima sehingga nilai pendapatan menjadi lebih besar dari pengeluaran yang dilakukan oleh pemerintah. Hal ini berarti bahwa setiap kebijakan alokasi belanja termasuk alokasi belanja modal di dalamnya mampu dipenuhi dengan baik sesuai dengan adanya penerimaan pendapatan yang maksimal yang diterima pemerintah. Oleh karena itu, efisiensi kinerja keuangan daerah secara signifikan mempengaruhi kebijakan alokasi belanja yang di dalamnya termasuk alokasi belanja modal.

Hasil penelitian ini sejalan dengan Vegasari (2011) menyebutkan bahwa efisiensi keuangan berpengaruh positif terhadap alokasi belanja modal. Namun penelitian ini tidak sejalan dengan Ardhini dan Handayani (2011) dan Martini dan Dwirandra (2015) yang menemukan bahwa efiseinsi keuangan tidak berpengaruh signifikan terhadap alokasi belanja modal.

\subsubsection{Pengaruh Kontribusi BUMD terhadap Alokasi Belanja Modal}

Hasil penelitian menunjukkan rasio kontribusi BUMD tidak berpengaruh signifikan terhadap alokasi belanja modal. Hal ini berarti bahwa perkembangan penerimaan daerah yang bersumber dari pendapatan BUMD tidak mampu memberikan efek terhadap 
peningkatan alokasi belanja modal pemerintah. Kondisi ini terjadi karena masih minimnya kontribusi BUMD dalam penerimaan daerah. Jumlah penerimaan dari BUMD yang relatif sangat kecil membuat jumlah penerimaan yang bersumber dari BUMD tersebut tidak mampu mempengaruhi kebijakan pemerintah dalam mengalokasikan belanja daerahnya terutama alokasi belanja modal. Alokasi belanja modal yang dilakukan oleh pemerintah daerah masih sangat bergantung pada komponen pendapatan lain selain pendapatan yang bersumber dari BUMD.

Hasil penelitian ini tidak sejalan dengan penelitian yang dilakukan oleh Sularso dan Restianto (2011) menemukan bahwa derajat kontribusi BUMD berpengaruh signifikan terhadap alokasi belanja modal. Bertentangan dengan Martini dan Dwirandra (2015) yang menemukan derajat kontribusi BUMD berpengaruh positif tidak signifikan pada alokasi belanja modal, Praza (2016) menyatakan derajat kontribusi BUMD berpengaruh negative signifikan terhadap alokasi belanja modal. Suwandi dan Tahar (2015) dan Arsa dan Setiawina (2015) menyatakan derajat kontribusi BUMD tidak berpengaruh terhadap alokasi belanja modal.

\subsubsection{Pengaruh Derajat Desentralisasi Fiskal terhadap Pertumbuhan Ekonomi Daerah}

Hasil penelitian menunjukkan bahwa derajat desentralisasi fiskal tidak berpengaruh signifikan terhadap pertumbuhan ekonomi daerah. Derajat desentralisasi fiskal yang diukur dengan rasio PAD terhadap total pendapatan daerah masih memilki efek yang sangat kecil terhadap pertumbuhan ekonomi, sehingga terjadinya peningkatan derajat desentralisasi fiskal tidak mampu mempengaruhi laju pertumbuhan ekonomi.

Penerapan desentralisasi fiskal antara lain dimaksudkan untuk mengurangi kesenjangan fiskal antar pemerintah daerah sehingga tidak terjadi adanya daerah yang lebih rendah kemampuan keuangannya antara satu daerah dengan daerah lainnya. Perimbangan keuangan antar daerah dalam kerangka pelaksanaan desentralisasi fiskal mempunyai pengertian bahwa kepada daerah diberikan kewenangan untuk mengatur dan memanfaatkan sumber keuangan sendiri dimana tidak ada perbedaan yang besar dalam sisi keuangan antara daerah satu dengan daerah lainnya. Hal ini dimaksudkan supaya pembangun lebih merata di semua pelosok daerah terutama di Provinsi Jambi. Dengan pelaksanaan desentralisasi fiskal diharapkan pembangunan tidak hanya dipusatkan di daerah-daerah perkotaan, tetapi juga mampu menjangkau seluruh wilayah di Provinsi Jambi.

Kesenjangan pendapatan antar daerah yang dilihat dari indikator desentralisasi pendapatan berdasarkan hasil penelitian ini tidak mempengaruhi pertumbuhan ekonomi. Hal ini berarti bahwa semakin besar perbedaan pendapatan daerah dengan daerah lainnya tidak memberikan efek yang signifikan untuk meningkatkan laju pertumbuhan ekonomi. Masih besarnya ketergantungan pemerintah daerah terhadap penerimaan dana transfer dari pemerintah pusat menjadi faktor yang membuat aspek penerimaan daerah tidak terlalu berimbas pada pertumbuhan ekonomi. Dengan besarnya ketergantungan daerah terhadap sumber penerimaan dari pusat, menunjukkan masih lemahnya kewernangan pusat dalam pengelolaan keuangan daerah. Pemerintah pusat masih memiliki andil yang besar dalam menetapkan kebijakan pengelolaan keuangan daerah. Kondisi inilah yang membuat desentralisasi pendapatan tidak berpengaruh signifikan terhadap pertumbuhan ekonomi.

Hasil Penelitian ini tidak sejalan dengan penelitian Oates (2003) yang menemukan desentralisasi fiscal dapat meningkatkan pertumbuhan ekonomi dan kesejahteraan masyarakat. Saputra (2010) menyatakan bahwa desentralisasi fiskal terhadap pertumbuhan ekonomi memiliki pengaruh yang negatif, bisa dikatakan semakin tinggi desentralisasi fiskal, semakin rendah pertumbuhan ekonomi. Namun penelitian ini sejalan dengan Throton (2007) yang mengatakan bahwa desentralisasi fiscal tidak berpengaruh pada pertumbuhan ekonomi, terutama pada pemerintahan dengan pendapatan yang terbatas.

\subsubsection{Pengaruh Pertumbuhan PAD terhadap Pertumbuhan Ekonomi Daerah}

Hasil penelitianmenunjukkan bahwa variabel kinerja keuangan yang secara langsung mempengaruhi pertumbuhan ekonomi yaitu rasio pertumbuhan PAD. Hal ini berarti bahwa peningkatan penerimaan daerah yang bersumber dari PAD pada setiap tahunnya akan mempengaruhi laju pertumbuhan ekonomi daerah. Kemampuan daerah untuk meningkatan sumber penerimaan PAD yang diukur dengan rasio pertumbuhan PAD sangat menentukan pemerintah dalam menerapkan kebijakan ekonomi daerah yang berimbas pada peningkatan laju pertumbuhan ekonomi.

$$
\text { Menurut Mardiasmo }
$$
pendapatan asli daerah adalah penerimaan yang diperoleh dari sektor pajak daerah, retribusi daerah, hasil perusahaan milik daerah, hasil pengeloalaan kekayaan daerah yang dipisahkan, dan lain-lain pendapatan asli daerah yang sah. Pertumbuhan PAD yang terjadi setiap tahun menunjukkan adanya peningkatan pendapatan yang berasal dari pajak, retribusi, hasil BUMD dan sumber PAD lainnya. Hal ini menunjukkan semakin meningkatnya kemampuan daerah dalam mengoptimalkan sumber-sumber pendapatan yang berasal dari daerah. Kondisi ini juga menjadi indikator terjadinya perkembangan perekonomian di suatu daerah. Semakin tinggi PAD yang diperoleh suatu daerah maka akan semakin tinggi pertumbuhan ekonomi di daerah tersebut. 
Hasil Penelitian ini sejalan dengan penelitian oleh Brata (2004) dan Tambunan (2006) yang menyatakan bahwa pertumbuhan PAD berpengaruh positif terhadap pertumbuhan ekonomi daerah. Penelitian ini bertentangan dengan penelitian Sewi (2015) di Kabupaten/Kota di Provinsi Bali tahun 2007 - 2013 yang menemukan pertumbuhan PAD tidak berpengaruh terhadap pertumbuhan ekonomi.

\subsubsection{Pengaruh Efektivitas PAD terhadap Pertumbuhan Ekonomi Daerah}

Hasil penelitian menunjukkan bahwa variabel kinerja keuangan yang secara langsung mempengaruhi pertumbuhan ekonomi yaitu efektivitas PAD. Hal ini berarti bahwa efektivitas kinerja pemerintah daerah dalam menggalang sumber peneriumaan daerah yang berasal dari PAD akan mempengaruhi laju pertumbuhan ekonomi daerah. Kemampuan daerah untuk meningkatan sumber penerimaan PAD yang diukur dengan rasio efektivitas PAD sangat menentukan pemerintah dalam menerapkan kebijakan ekonomi daerah yang berimbas pada peningkatan laju pertumbuhan ekonomi.

Efektivitas PAD menunjukkan bahwa daerah mampu mencapai target penerimaan PAD sesuai dengan yang ditargetkan dalam APBD. Semakin tinggi rasio efektivitas berarti semakin besar jumlah realisasi PAD jika dibandingkan dengan target PAD yang dianggarkan. Data efektivitas PAD Kabupaten/Kota di Provinsi Jambi menunjukkan bahwa pemerintah daerah tergolong efektif dalam pencapaian target penerimaan PAD dengan rata-rata rasio efektivitas PAD sebesar 113,4\%. Dengan demikian, rata-rata kabupaten/kota di Provinsi Jambi mampu menghasilkan penerimaan PAD jauh di atas target yang ditetapkan dalam anggaran.

Penetapan target penerimaan PAD dalam anggaran disesuaikan dengan kemampuan perekonomian daerah yang diukur melalui Pendapatan Domestik Regional Bruto (PDRB). Semakin besar PDRB maka target penerimaan PAD di dalam APBD juga akan mengalami peningkatan. Oleh karena itu, jika daerah mampu mencapai efektivtas penerimaan PAD bahkan melebih dari target yang ditetapkan berarti bahwa perekonomian daerah masih mampu mendukung pencapaian target tersebut. Peningkatan target PAD pada tahun berikutnya masih memungkinkan dan apabila setelah ditingkatkan target yang ditetapkan masih tercapai, berarti terjadi perkembangan kondisi perekonomian di wilayah tersebut. Hal inilah yang membuat rasio efektivitas PAD secara signifikan mampu mempengaruhi pertumbuhan ekonomi daerah.

Hasil penelitian ini sejalan dengan penelitian Yuliani (2017) mengungkapkan bahwa efektivitas PAD berpengaruh positif signifikan terhadap pertumbuhan ekonomi. Tetapi penelitian ini tidak sejalan dengan penelitian Randa dan Paledung (2012) yang mengatakan bahwa kemampuan daerah dalam menjalankan tugas belum efektif oleh karena itu menunjukan pengaruh efektivitas PAD tidak berpengaruh terhadap pertumbuhan ekonomi.

\subsubsection{Pengaruh Efisiensi Keuangan terhadap Pertumbuhan Ekonomi Daerah}

Hasil penelitian menunjukkan bahwa rasio efisiensi secara langsung mempengaruhi pertumbuhan ekonomi daerah.Kebijakan pemerintah daerah dalam melakukan efisiensi keuangan dengan menekan jumlah alokasi belanja dan mengoptimalkan pendapatan daerah berimbas pada laju pertumbuhan ekonomi. Dengan demikian, adanya peningkatan ataupun penurunan efisiensi keuangan daerah akan mempengaruhi perkembangan perekonomian kabupaten/kota di Provinsi Jambi secara signifikan.

Pertumbuhan ekonomi dipengaruhi oleh kebijakan daerah dalam menekan pengeluaran pemerintah sehingga nilainya lebih rendah dari jumlah pendapatan. Pertumbuhan ekonomi justru sangat dipengaruhi oleh kebijakan pemerintah dalam melaksanakan pembangunan yang tertuang dalam alokasi pembelanjaan daerah terutama pada alokasi belanja langsung pemerintah. Namun, alokasi belanja yang besar harus diiringi oleh besarnya penerimaan daerah terutama penerimaan yang bersumber dari daerah itu sendiri. Tetapi dalam kenyataannya di Kabupaten/Kota di Provinsi Jambi masih sangat bergantung pada penerimaan yang bersumber dari pemerintah pusat.

Penelitian ini tidak sejalan dengan penelitian dari Yuliani (2017) menunjukan bahwa rata-rata Kabupaten/kota provinsi Jawa Barat belum bisa dikatakan efisien dalam mengelola pendapatan dan belanjanya sehingga penelitianya mendapatkan hasil efisiensi keuangan tidak berpengaruh signifikan terhadap pertumbuhan ekonomi.

\subsubsection{Pengaruh Kontribusi BUMD terhadap Pertumbuhan Ekonomi Daerah}

Hasil penelitian menunjukkan bahwa rasio kontribusi BUMD tidak berpengaruh signifikan terhadap pertumbuhan ekonomi daerah. Hal ini berarti bahwa peningkatan pendapatan daerah yang bersumber dari penerimaan BUMD tidak mampu memberikan efek yang signifikan terhadap laju pertumbuhan ekonomi. Kontribusi BUMD terhadap pertumbuhan ekonomi daerah masih minim sehingga walaupun setiap tahun terjadi peningkatan penerimaan yang bersumber dari BUMD tidak memberikan imbas terhadap kondisi perekonomian di daerah.

Secara makro, peranan PD/BUMD terhadap perekonomian daerah dapat diukur melalui kontribusi nilai tambahnya terhadap Pendapatan Domestik Regional Bruto (PDRB) dan kemampuannya menyerap tenaga kerja. Sebagai wujud nyata dari investasi daerah, BUMD mau tidak mau akan 
menghadapi persaingan yang semakin tinggi dengan masuknya pasar global. Pilihannya adalah apakah BUMD tersebut harus tetap dengan kondisinya saat ini atau mengikuti persaingan itu dengan melakukan perubahan pada visi, misi, dan strategi bisnisnya. Melihat dari fungsinya, BUMD didirikan bertujuan untuk turut serta melaksanakan pembangunan daerah khususnya dan pembangunan ekonomi nasional umumnya untuk memenuhi kebutuhan rakyat menuju masyarakat yang adil dan makmur. Namun, hingga saat ini tujuan tersebut belum secara nyata diwujudkan oleh PD/BUMD. Kontribusi BUMD dalam menghasilkan PAD masih sangat minim. Minimnya kontribusi BUMD inilah yang membuat kontribusi BUMD tidak signifikan mempengaruhi pertumbuhan ekonomi daerah.

Hasil Penelitian ini tidak sejalan dengan penelitian Zulyanto (2010) mengindikasikan bahwa terdapat pengaruh yang positif dan signifikan antara pendapatan BUMD terhadap pertumbuhan ekonomi di Provinsi Bengkulu. Tudak sejalan dengan penelitian Sukarmi dan Budiasih (2016) mengatakan hasil penelitianya bahwa kontribusi BUMD tidak berpengaruh signifikan terhadap pertumbuhan ekonomi.

\subsubsection{Pengaruh Alokasi Belanja Modal terhadap Pertumbuhan Ekonomi Daerah}

Hasil penelitian ini menunjukkan bahwa alokasi belanja modal berpengaruh signifikan terhadap pertumbuhan ekonomi daerah di Provinsi Jambi. Hasil penelitian ini sesuai dengan pendapat Halim (2008) yang mengungkapkan bahwa Belanja Modal merupakan bentuk investasi yang berupa capital expenditure sebagai belanja/biaya/pengeluaran yang memberi manfaat lebih dari satu tahun tetapi harus memperhatikan aspek tujuan dan arah yang terkait dengan aspek ekonomis dan di luar kriteria rasionalitas ekonomis, bahkan dimensi moral pun masuk dalam ranah kebijakan investasi sektor publik.

Sebagai generator pertumbuhan kawasan, keberhasilan investasi tidak dapat diukur dengan pengembalian dana yang secara langsung diperoleh dari obyek investasi semata, tetapi dengan mengukur seberapa jauh aktivitas ikutan atau lingkungan kawasan mampu menciptakan kegiatan ekonomi ikutan yang dikelola kemudian hari sehingga mampu dikembangkan menjadi sumber-sumber penerimaan daerah. Kriteria ini penting karena fungsi belanja modal sebagai investasi sektor publik dalam pengembangan kawasan justru pada seberapa besar keberhasilan menciptakan aktivitas perekonomian di kawasan tersebut.

Hasil penelitian ini sejalan dengan penelitian Kuncoro (2004). Namun penelitian ini tidak sejalan dengan hasil penelitian Anasemen (2009) pada Kabupaten/Kota di Provinsi Sumatera Barat tahun 2000-2006, begitu juga hasil penelitian Yahya (2009) pada Kabupaten/Kota di Sumatera Utara tahun 20042007, yang menyatakan bahwa belanja modal tidak berpengaruh signifikan terhadap pertumbuhan ekonomi.

\subsubsection{Pengaruh Derajat Desentralisasi Fiskal terhadap Pertumbuhan Ekonomi Daerah yang dimediasi oleh Alokasi Belanja Modal}

Hasil penelitian menunjukkan bahwa derajat desentralisasi fiskal secara tidak langsung tidak mempengaruhi pertumbuhan ekonomi.Hal ini berarti bahwa peningkatan derajat desentralisasi fiskal melalui mediasi alokasi belanja modal mampu meningkatkan laju pertumbuhan ekonomi.Dengan demikian, derajat desentralisasi fiskal mampu meningkatkan alokasi belanja modal, sehingga memberikan efek tidak langsung melalui belanja modal terhadap pertumbuhan ekonomi.

Kesenjangan pengeluaran antar kabupaten/kota di Provinsi Jambi yang ditunjukkan dengan indikator desentralisasi pengeluaran menunjukkan pengaruh yang negatif terhadap pertumbuhan ekonomi.Hal ini berarti bahwa semakin besar perbedaan pengeluaran pemerintah daerah justru mengakibatkan terjadinya penurunan laju pertumbuhan ekonomi.Kondisi ini disebabkan oleh karena belum efektifnya kebijakan belanja daerah yang dilakukan oleh kabupaten/kota di Provinsi Jambi.Masih rendahnya alokasi belanja yang ditujukan untuk pembangunan infrastruktur menjadi faktor utama yang mengakibatkan perbedaan jumlah belanja daerah justru berpengaruh negatif terhadap pertumbuhan ekonomi.Daerah dengan pengeluaraan yang lebih besar justru lebih banyak mengalokasikan belanja daerahnya untuk belanja rutin yang tidak secara langsung mempengaruhi pertumbuhan ekonomi, sedangkan alokasi belanja modalnya justru lebih kecil.

Hasil penelitian ini sejalan dengan penelitian Arsa dan Setiawina (2015) menemukan bahwa desentralisasi fiskal berpengaruh tidak langsung terhadap pertumbuhan ekonomi melalui belanja modal. Penelitian ini bertentangan dengan penelitian yang dilakukan oleh Sularso dan Restianto (2011) yang menunjukan bahwa belanja modal tidak memediasi pengaruh desentralisasi fiscal terhadap pertumbuhan ekonomi.

\subsubsection{Pengaruh Pertumbuhan PAD terhadap Pertumbuhan Ekonomi Daerah yang dimediasi oleh Alokasi Belanja Modal}

Hasil penelitian menunjukkan bahwa rasio pertumbuhan PAD dalam mempengaruhi pertumbuah ekonomi tidak dimediasi oleh alokasi belanja modal sebagai variabel intervening. Hal ini berarti bahwa walaupun alokasi belanja modal mampu mempengaruhi pertumbuhan ekonomi daerah, tetapi, karena pertumbuhan PAD tidak berpengaruh terhadap alokasi belanja modal membuat variabel belanja 
modal bukan variabel mediasi yang tepat yang menghubungkan pertumbuhan PAD dengan pertumbuhan ekonomi.

Alokasi belanja modal mampu memediasi pengaruh pertumbuhan PAD terhadap pertumbuhan ekonomi jika pertumbuhan PAD secara signifikan mempengaruhi belanja modal dan belanja modal juga secara signifikan mempengaruhi pertumbuhan ekonomi. Proporsi PAD dalam total penerimaan daerah yang menjadi sumber pembiyaan alokasi belanja masih rendah sehingga daerah dalam mengalokasikan belanja terutama alokasi belanja modal masih tergantung pada sumber penerimaan dari pemerintah pusat. Akibatnya, walaupun terjadi pertumbuhan PAD pada setiap tahunnya tidak memberikan efek yang besar yang bisa mempengaruhi kebijakan pemerintah daerah dalam menetapkan alokasi belanja modal. Karena kebijakan alokasi belanja modal tidak dipengaruhi oleh pertumbuhan PAD, walaupun belanja modal itu sendiri secara langsung mampu mempengaruhi pertumbuhan ekonomi, membuat variabel belanja tidak mampu memediasi pengaruh pertumbuhan PAD terhadap pertumbuhan ekonomi.Hasil penelitian ini tidak sejalan dengan penelitian oleh Taiwo dan Abayomi (2011).

\subsubsection{Pengaruh Efektivitas PAD terhadap Pertumbuhan Ekonomi Daerah yang dimediasi oleh Alokasi Belanja Modal}

Hasil penelitian ini menunjukkan bahwa efektivitas PAD dalam mempengaruhi pertumbuhan ekonomi dimediasi oleh alokasi belanja modal. Hal ini berarti semakin efektif kinerja keuangan daerah yang berhubungan dengan pencapaian target PAD dalam APBD, kondisi tersebut mampu menjadi faktor yang mempengaruhi kebijakan pemerintah daerah dalam penetapan alokasi belanja daerah. Sementara itu, belanja modal merupakan faktor yang secara signifikan mempengruhi pertumbuhan ekonomi, sehingga dengan kebijakan alokasi belanja modal ditentukan oleh efektivitas kinerja keuangan pemerintah, maka belanja modal akan mampu memediasi pengaruh rasio efektivitas terhadap pertumbuhan ekonomi.

Penyediaan infrastruktur yang secara langsung berhubungan dengan pelayanan terhadap masyarakat seperti jalan, jembatan, irigasi dan lain sebagainya akan mendorong perkembangan ekonomi di daerah. Penyediaan infrastrukur tersebut merupakan kebijakan pemerintah daerah melalui penetapan alokasi belanja modal dalam APBD. Semakin besar alokasi belanja modal berarti semakin besar juga konsentrasi pemerintah dalam mengembangan perekonomian daerah tersebut.

Pada sisi lain, kebijakan alokasi belanja modal sangat dipengaruhi oleh sumber penerimaan daerah dimana sumber utama penerimaan daerah berasal dari PAD. Semakin tinggi jumlah penerimaan PAD akan mempengaruhi kebijakan pemerintah dalam mengalokasikan belanja daerahnya terutama alokasi belanja modalnya.Hasil penelitian ini sejalan dengan penelitian Utomo (2012), Sularso dan Restianto (2012) serta Arsa dan Setiawina (2015) menyatakan bahwa belanja modal memediasi hubungan antara efektivitas PAD dengan pertumbuhan ekonomi.

\subsubsection{Pengaruh Efisiensi Keuangan terhadap Pertumbuhan Ekonomi Daerah yang dimediasi oleh Alokasi Belanja Modal}

Efisiensi belanja daerah yang merupakan perbandingan antara penerimaan daerah dengan total belanja daerah. Nilai rasio efisiensi di bawah $100 \%$ berarti bahwa daerah mampu menekan pengeluaran daerah secara efisien dengan nilai belanja daerah lebih rendah dibandingkan dengan penerimaan daerah pada tahun berjalan. Sebaliknya jika rasio efisiensi di atas $100 \%$ menunjukkan bahwa APBD kurang efisien dimana pengeluaran pemerintah daerah melebihi penerimaan.

Berdasarkan hasil penelitian ini dibuktikan bahwa efisiensi belanja daerah secara langsung mempengaruhi alokasi belanja modal, tapi tidak mempengaruhi pertumbuhan ekonomi. Pengaruh rasio efisiensi dimediasi oleh faktor belanja modal, dalam arti bahwa pencapaian efisiensi APBD akan mempengaruhi kebijakan pemerintah daerah dalam menetapkan alokasi belanja daerah yang kemudian berimbas pada laju pertumbuhan ekonomi.Hasil penelitian ini sejalan dengan penelitian Ani dan Dwirandra (2014) dan Astuti (2015).

\subsubsection{Pengaruh Kontribusi BUMD terhadap Pertumbuhan Ekonomi Daerah yang dimediasi oleh Alokasi Belanja Modal}

Hasil penelitian menunjukkan bahwa rasio kontribusi BUMD tidak dimediasi oleh alokasi belanja modal dalam mempengaruhi pertumbuhan ekonomi. Kontribusi BUMD tidak memberikan efek terhadap kebijakan pemerintah daerah dalam mengalokasikan belanja modalnya. Karena kontribusi BUMD tidak mempengaruhi alokasi belanja modal, walaupun belanja modal secara langsung mempengaruhi pertumbuhan ekonomi, tetapi belanja modal tersebut tidak memediasi pengaruh kontribusi BUMD terhadap pertumbuhan ekonomi.

Pembiayaan belanja daerah baik alokasi belanja langsung maupun belanja tidak langsung pemerintah daerah di Kabupaten/Kota di Provinsi Jambi masih sangat bergantung pada sumber pembiyaan yang berasal dari dana transfer pemerintah pusat. Kontribusi penerimaan yang berasal dari daerah sendiri belum mampu memberikan efek yang signifikan dalam membiayai alokasi belanja daerah. Sementara itu, pendapatan daerah yang berasal dari hasil pengelolaan BUMD masih sangat minim. 
Minimnya kontribusi BUMD dalam pendapatan daerah membuat variabel tersebut tidak mempengaruhi kebijakan daerah dalam menetapkan alokasi belanja modalnya. Karena kontribusi BUMD tidak memberikan efek terhadap alokasi belanja modal, membuat variabel belanja modal tidak mampu memediasi pengaruh kontribusi BUMD terhadap pertumbuhan ekonomi.Hasil Penelitian ini tidak sejalan dengan penelitian Utomo (2012) serta Arsa dan Setiawina (2015) menyatakan bahwa belanja modal memediasi hubungan antara derajat kontribusi BUMD dengan pertumbuhan ekonomi.

\section{SIMPULAN DAN SARAN}

\subsection{Simpulan}

Berdasarkan hasil pengujian hipotesis dan pembahasan dapat disimpulkan hal-hal sebagai berikut:

1. Derajat desentralisasi fiscal berpengaruh langsung terhadap alokasi belanja modal Kabupaten/Kota di Provinsi Jambi.

2. Pertumbuhan PAD tidak berpengaruh langsung terhadap alokasi belanja modal Kabupaten/Kota di Provinsi Jambi.

3. Efektivitas PAD berpengaruh langsung terhadap alokasi belanja modal Kabupaten/Kota di Provinsi Jambi.

4. Efisiensi Keuanganberpengaruh langsung terhadap alokasi belanja modal Kabupaten/Kota di Provinsi Jambi.

5. Kontribusi BUMD tidak berpengaruh langsung terhadap alokasi belanja modal Kabupaten/Kota di Provinsi Jambi.

6. Derajat desentralisasi fiscal tidak berpengaruh langsung terhadap pertumbuhan ekonomi Kabupaten/Kota di Provinsi Jambi.

7. Pertumbuhan PAD berpengaruh langsung terhadap pertumbuhan ekonomi Kabupaten/Kota di Provinsi Jambi.

8. Efektivitas PAD berpengaruh langsung terhadap pertumbuhan ekonomi Kabupaten/Kota di Provinsi Jambi.

9. Efisiensi berpengaruh langsung terhadap pertumbuhan ekonomi Kabupaten/Kota di Provinsi Jambi.

10. Kontribusi BUMD tidak berpengaruh langsung terhadap pertumbuhan ekonomi Kabupaten/Kota di Provinsi Jambi.

11. Belanja modal berpengaruh langsung terhadap pertumbuhan ekonomi Kabupaten/Kota di Provinsi Jambi.
12. Belanja modal memediasi pengaruh derajat desentralisasi fiskal terhadap pertumbuhan ekonomi Kabupaten/Kota di Provinsi Jambi.

13. Belanja modal tidak memediasi pengaruh pertumbuhan PAD terhadap pertumbuhan ekonomi Kabupaten/Kota di Provinsi Jambi.

14. Belanja modal memediasi pengaruh efektivitas PAD terhadap pertumbuhan ekonomi Kabupaten/Kota di Provinsi Jambi.

15. Belanja modal memediasi pengaruh efisiensi terhadap pertumbuhan ekonomi Kabupaten/Kota di Provinsi Jambi.

16. Belanja modal tidak memediasi pengaruh kontribusi BUMD terhadap pertumbuhan ekonomi Kabupaten/Kota di Provinsi Jambi.

\subsection{Saran}

Berdasarkan keterbatasan, kesimpulan dan implikasi hasil penelitian ini sebagaimana diuraikan di atas, maka peneliti menyumbangkan saran sebagai berikut:

1. Bagi Pemerintah Kabupaten/Kota di Provinsi Jambi supaya meningkatkan alokasi belanja modal yang terbukti berpengaruh secara langsung terhadap pertumbuhan ekonomi.

2. Bagi Pemerintah Kabupaten/Kota di Provinsi Jambisupaya meningkatkan efektivitas penerimaan PAD yang terbukti secara langsung mempengaruhi alokasi belanja modal dan pertumbuhan ekonomi.

3. Bagi Pemerintah Kabupaten/Kota di Provinsi Jambisupaya meningkatkan efisiensi APBD yang terbukti secara langsung mempengaruhi alokasi belanja modal dan pertumbuhan ekonomi.

4. Bagi peneliti selanjutnya supaya melakukan penelitian dengan subjek penelitian yang lebih beragam misalnya dengan menggunakan beberapa kabupaten di seluruh Indonesia.

5. Bagi peneliti selanjutnya supaya menggunakan faktor-faktor lainnya sebagai variabel yang mempengaruhi pertumbuhan ekonomi dan belanja modal seperti dana alokasi umum, dana alokasi khusus, dana bagi hasil, dan lain sebagainya.

\section{DAFTAR REFERENSI}

Abdul, H., \& Muhammad, S.K. 2012.Teori, Konsep dan Aplikasi Akuntansi Sektor Publik. Jakarta : SalembaEmpat.

Adi, P.H. 2007. “ Hubungan anatara PertumbuhanEkonomi Daerah, Belanja 
Pembangunan dan Pendapatan Asli Daerah (Studi pada Kabupaten dan Kota se JawaBali) '. Jurnal Akuntansi dan Keuangan Sektor Publik, Vol 08, No.1.

Ardhani, Pungky. 2011. Pengaruh Pertumbuhan ekonomi, Pendapatan Asli Daerah, Dana Alokasi Umum, dan Dana Alokasi Khusus terhadap PengalokasianAnggaran Belanja Modal (Studi pada Pemerintah Kabupaten/Kota di Jawa Tengah). Tesis Universitas Diponegoro. Semarang.

Ardhini dan Sri Handayani. 2011. Pengaruh Rasio Keuangan Daerah Terhadap Belanja Modal untuk Pelayanan Publik dalam Perspektif Teori Keagenan (Studi pada Kabupaten dan Kota di Jawa Tengah). Undergraduate Thesis. Universitas Diponegoro.

Arsa, Ketut. 2015. Pengaruh kinerja keuangan pada alokasi belanja modal dan pertumbuhan ekonomi pemerintah kabupaten/ kota seProvinsi Bali Tahun 2006 S.d. 2013. Jurnal Buletin Studi Ekonomi Vol 20 No.2.

Arsa, I.K dan Setiawina, N.D. 2015. "Pengaruh Kinerja Keuangan Pada Alokasi Belanja Modal dan Pertumbuhan Ekonomi Pemerintah Kabupaten/ Kota Se-Provinsi Bali Tahun 2006 s.d. 2013. "Jurnal Buletin Studi Ekonomi, Vol. 20104 No.2

Andrifa. 2016. Pengaruh Belanja Modal, dana perimbangan dan pendapatan Asli Daerah terhadap Kinerja Keuangan Kabupaten dan kota di Provinsi Aceh.

Ani \& Dwirandra. 2012. Pengaruh Kinerja Keuangan pada Pertumbuhan Ekonomi, Pengangguran, dan Kemiskinan Kabupaten dan Kota.

Bastian.Indra., 2001. Akuntansi Sektor Publik di Indonesia. Yogyakarta: BPFE-Yogyakarta.

Bastian.Indra, 2006. Akuntansi Sektor Publik. Suatu Pengantar Jakarta: Erlangga.

BPKP, 2012. Petunjuk Penyusunan Kompilasi Laporan Keuangan dan Analisis Kinerja Keuangan Pemerintah Daerah (Revisi).

BPS (2017). Jambi Dalam Angaka 2016. Jambi : badan Pusat Statistik.

BPS (2017). Statistik Keuangan Pemerintah Daerah Provinsi Jambi 2011-2016 Jambi : badan Pusat Statistik.

BPS (2017). Produk Domestik Regional Bruto Provinsi Jambi 2011-2016 Jambi : badan Pusat Statistik.
Budiarto, Bambang. 2007. Pengukuran Keberhasilan Pengelolaan Keuangan Daerah. Surabaya: Seminar Ekonomi Daerah.

Darwanto dan Yustika Sari, Yulia. 2007. Pengaruh Pertumbuhan Ekonomi, Pendapatan Asli Daerah, dan dana Alokasi umum terhadap Pengalokasian Anggaran Belanja Modal. SNA X.

Deddi Nordiawan. 2007. Akuntansi Sektor Publik. Jakarta: Salemba Empat.

Deddi Nordiawan dan Ayuningtyas Hertianti. 2011. Akuntansi Sektor Publik. Jakarta: Salemba Empat.

Dinarossi. 2016. Pengaruh Efisiensi dan Kemandirian Keuangan Daerah Terhadap Belanja Modal di Wilayah Sumatera Selatan. Jurnal Adminika Volume 2.No.2 Juli Desember 2016.

Ferdinand A. 2002. Structural Equation Modeling dalam Penelitian Manajemen. Aplikasi Model-Model Rumit dalam Penelitia nuntuk Tesis $S$-2 dan Disertasi $S$-3, BP Universitas Diponegoro Semarang.

Ghozali, Imam. 2011. Aplikasi Analisis Multivariate dengan Program SPSS.

Semarang: Edisi 5. Semarang: Badan Penerbit Universitas Diponegoro.

Ghozali, Imam. 2017. Model Persamaan Stuktural konsep dan aplikasi dengan program Amos 24. Semarang: Edisi 7. Semarang: Badan Penerbit Universitas Diponegoro.

Halim, A. 2007.Akuntansi Sektor Publik. Edisi Tiga: Penerbit Salemba.

Halim,Abdul.2007.Bunga Rampai Manajemen Keuangan Daerah Yogjakarta, UPP AMPYKPN.

Halim, Abdul. 2008. Auditing (Dasar-dasar Audit LaporanKeuangan). Yogyakarta: Unit PenerbitdanPercetakan STIMYKPN.

Hamzah,A. 2008. Analisa Kinerja Keuangan terhadap Pertumbuhan Ekonomi, Pengangguraan dan Kemiskinan: Pendekatan Analisa Jalur, Universitas Trunojoyo

Hanafi, Imam dan Nugroho,T. 2009. Kebijakan Keuangan Daerah: Reformasi dan Model Pengelolaan Keuangan Daerah di Indonesia. Malang: UBPress.

Halim, Abdul. 2008. Akuntansi Keuangan Daerah. Edisi 3. Jakarta: Salemba Empat.

Halim, A., dan Kusufi, M.S. 2013.Akuntansi Sektor Publik: Akuntansi Keuangan Daerah.Jakarta : Salemba Empat. 
Halim, Abdul. 2014. Manajemen Keuangan Sektor Publik Jakarta: Salemba Empat.

Hair, J.F., Aderson, R.e, Tatham, R.L., and Black, W.C. 1998. Multivariete Data Analysis $\left(4^{\text {th }}\right.$. Ed.). New Jersey. Prentice-Hall, Inc.

Hidayat, Mochammad Fajar. 2013. Analisis Pengaruh Kinerja Keuangan Daerah terhadap Alokasi Belanja Modal. Jurnal Ilmiah Mahasiswa Fakultas Ekonomi dan Bisnis (JIMFEB),1 (2): $1-21$.

Hygi, Asepma. 2015. Pengaruh kinerja Keuangan terhadap Alokasi Belanja Modal dan Pertumbuhan Ekonomi di Kabupaten/ Kota Riau. Jurnal Sorot, Volume 10 Nomor 2.

Huda, Ahmad Syahral. 2015. Pengaruh Kinerja Keuangan, Fiscal Stress, dan Kepadatan Penduduk Terhadap Alokasi Belanja Modal di Nusa Tenggara Barat. ASSETS,5 (2): 1-12.

Jamzani, Sodik. 2007. Pengeluaran Pemerintahdan Pertumbuhan Ekonomi Regional: Studi Kasus Data Panel di Indonesia. Jurnal Ekonomi Pembangunan Vol.12 No.1: 27-36.

Jatitmas, Rilo. 2015. Pengaruh Rasio Keuangan Terhadap Alokasi Belanja Modal pada Kabupaten/ Kota di Provinsi Jawa Tengah. Jurnal Akuntansi dan Sistem Teknologi Informasi, 11 (1): 50-57.

Jhingan, M. L. 1994. Ekonomi Pembangunan dan Perencanaan. Diterjemahkan oleh D. Guritno. Jakarta: Raja Grafindo Persada.

Ji, Tao dan Jianhui Zhang. 2011. Effect of Local Government Expenditure on Ratio Output to Capital: Evidence From Panel Data at China's Provincial level. Frot. Econ. China, 6 (2): 249270.

Kuncoro, Mudrajad.2004. Otonomi dan Pembangunan Daerah. Jakarta: Erlangga.

Kusnandar dan Dodik Siswantoro. 2012. "Pengaruh Dana Alokasi Umum, Pendapatan Asli Daerah, Sisa Lebih Pembiayaan Anggaran dan Luas Wilayah Terhadap Belanja Modal". Jurnal Akuntansi. Jakarta: Universitas Indonesia.

Ma'aru, Ahmad danWihastuti, Latri. Pertumbuhan Ekonomi Indonesia: Determinan dan Prospeknya, Jurnal Ekonomi dan Studi Pembangunan, Volume 9, Nomor 1, April 2008.

Mahmudi. 2011. Akuntansi SektorPublik. Yogyakarta: Penerbit UII Press.

Mankiw, Gregony. 2006. PengantarEkonomiMikro. Jakarta: SalembaEmpat.
Mardiasmo, 2002. Akuntansi Sektor Publik. Yogyakarta: Andi Offset.

Martini, Kadek. 2015. Pengaruh Kinerja Keuangan Daerah pada Alokasi Belanja Modal di Provinsi Bali. E-Jurnal Akuntansi Universitas Udayana 10 (2): 426-443.

Michael Todaro. 2000. Pembangunan Ekonomi Di dunia ketiga, Erlangga, Jakarta.

Mondes, 2016. Analisis Kinerja Keuangan Pemerintah Provinsi Jambi dan Pengaruhnya terhadap Pertumbuhan Ekonomi, Jurnal Prespektif dan Pembangunan Daerah Vol.4 No.2.

Maryati, Ulfi dkk. 2010. Pengaruh Pendapatan Asli Daerah (PAD), Dana Alokasi Umum (DAU) dan Dana Alokasi Khusus (DAK) terhadap Pertumbuhan Ekonomi: Studi Kasus Sumatera Barat: Jurnal Akuntansi dan Manajemen. Volume V, Nomor 2 hal 69.

Nurcholis, Hanif. 2007. Teori dan Praktik Pemerintahan dan Otonomi Daerah. Jakarta: Grasindo.

Peraturan Pemerintah Nomor 24 Tahun 2010 tentang Standar Akuntansi Pemerintahan

Peraturan Pemerintah Nomor 71 Tahun 2010 tentang Standar Akuntansi Pemerintahan.

Prakarsa, FebrianDwi. 2014. Analisis Pengaruh Pendapatan Asli Daerah dan Pengeluaran Pemerintah Daerah terhadap Pertumbuhan Ekonomi (Studi Kasus di Kabupaten/ Kota Jawa Timur Tahun 2008-2012): Jurnal Ilmiah, Agustus.

Purbadharmaja.2006. Implikasi Variabel Pengeluaran dan Investasi Terhadap Pertumbuhan Ekonomi Provinsi Bali. Jurnal Buletin Studi Ekonomi Vol. 11 No. 1: 79-91.ISSN, 14104638.

Pekei, B. 2016. Konsep dan Analisa Efektif Pengelolaan Keuangan Daerah Otonomi. Jakarta: Tausah.

Praza, Eko Indra. 2016. Analisis Pengaruh Kinerja Keuangan terhadap Alokasi Belanja Modal di Provinsi Jambi. Jurnal Prespektif dan Pembangunan Daerah , 4(1): 25-35.

Rizani, dkk. 2011. Pengaruh pertumbuhan Ekonomi, Pendapatan Daerah, Dana Alokasi Umum dan Dana Alokasi Khusus Pada Belanja Daerah Pemerintah Kota di Provinsi kalimantan Selatan. JEPMA Vol. 10, No. 1 April hal. 1927.

Republik Indonesia. 2004. Undang-Undang Republik Indonesia Nomor 32 Tahun 2004 tentang Pemerintahan Daerah. 
Republik Indonesia. 2004. Undang-Undang Republik Indonesia Nomor 33 Tahun2004 tentang Perimbangan Keuangan antara Pemerintahan Pusatdan Pemerintahan Daerah.

Republik Indonesia. 2014. Undang-Undang Republik Indonesia Nomor 23 Tahun2014 tentang Pemerintahan Daerah.

Republik Indonesia. 2005. Peraturan Pemerintah No.58 Tahun 2005 tentang Pengelolaan Keuangan Daerah. Jakarta: Legalitas.

Republik Indonesia. 2006. Pemendagri No.13 Tahun 2006 tentang Pedoman Pengelolaan Keuangan Daerah. Jakarta: Legalitas.

Ridwan, Kuncoro Engkos Achmad. 2007. Cara menggunakan dan Memaknai Analisis Jalur (Path Analysis). Cetakan Pertama. Bandung : Alfabeta.

Rosemary O Ananazodo, igbokwe-Ibeto, Chinyeaka Justine, and NKOMAH, Barisua Barry. 2016. Local Government Financial Autonomy: A Comparative Analysis of Nigeria and Brazil. Arabian Journal of Business and Management Review, 5(10): 38-54.

Saggaf, Said. 1999. “Analisa Pengaruh Pendapatan Asli Daerah terhadap Peningkatan Pertumbuhan Ekonomi di Kotamadya Pekanbaru”. Tesis Progres Pascasarjana USU Medan.

Samuelson, Paul A danNordhaus, William D. 1995.Makro Ekonomi. Jakarta: IKAPI.

Saragih, Juli Panglima. 2003. Desentralisasi Fiskal dan Keuangan Daerah.

Sanusi. Anwar. 2011. Metode Penelitian Bisnis Jakarta: Salemba Empat.

Sirojuzilam. 2008. Disparitas Ekonomi dan Perencanaan Regional, Ketetimpangan Ekonomi wilayah Barat dan Wilayah Timur Provinsi Sumatera Utara. Pustaka Bangsa Press.

Sularso dan Restianto.2016. Pengaruh Kinerja Keuangan terhadap Alokasi Belanja Modal dan Pertumbuhan Ekonomi Kabupaten/ Kota di Jawa Tengah. Jurnal ISSN 2088-2016.

Suprapto. 2009. KomunikasiOrganisasiEdisi V. Jakarta :Cetakan ketujuh.

Sugiyono. 2010. Metode Penelitian Pendidikan Pendekatan Kuantitatif, kualitatif, dan R\&D. Bandung: Alfabeta.

Susantih, Heny, \&Saftianayulia. 2009. Perbandingan Indikator Kinerja Keuangan Pemerintah Propinsi Se-Sumatera Bagian
Selatan. Simposium Nasional Akuntansi XI. Palembang.

Suwandi,K.A., \&Tahar, A. 2015. Pengaruh Kinerja Keuangan Terhadap Pertumbuhan Ekonomi Daerah dengan Alokasi Belanja Modal Sebagai Variabel Intervening (Studi Pada Pemerintah Kabupaten/ Kota D.I Yogyakarta) Jurnal Infestasi, 11 No.2, 118136.

Todaro, 2000. Pembangunan Ekonomi di Dunia Ketiga. Jilid I, Edisi Keenam, Jakarta: Erlangga.

Zulyanto, Aan. 2010. “ Pengaruh Desentralisasi Fiskal terhadap Pertumbuhan Ekonomi di Provinsi Bengkulu. Tesis Dipubulikasikan. Magister Ilmu Ekonomi dan Studi Pembangnan, Fakultas Ekonomika dan Bisnis. Universitas Diponegoro. Semarang. 